APPENDIX II

附錄二

\title{
Awards for Services 服務貢獻獎
}

\section{Exceptional Service Award 特殊服務貢獻獎}

In 2017, three Exceptional Service Awards were granted to three recipients upon their retirement: two members of the Li Fang-Kuei Society Board of Directors and one member of the Bulletin of Chinese Linguistics.

Professor Hung-Nin Samuel Cheung (Executive Secretary of the Li Fang-Kuei Society for Chinese Linguistics, Member of the LFK Society Board of Directors, Editor-in-Chief for the Bulletin of Chinese Linguistics)

Professor Ho Dah-An (Member of the LFK Society Board of Directors, Editor-in-Chief for the Bulletin of Chinese Linguistics, Chair of the Preparatory Committee for the Second Li Fang-Kuei Society Young Scholars Symposium)

Professor Zhang Min (Editor-in-Chief for the Bulletin of Chinese Linguistics, Keynote Speaker of the First Li Fang-Kuei Society Young Scholars Symposium)

Details are given in the LFK Society web site: www.lfksociety.org.

\section{Award for Excellent Reviewer 優秀審查人獎}

The Award for Excellent Reviewer was set up in 2019 in appreciation of service rendered to the Li FangKuei Society for Chinese Linguistics in providing excellent reviews to the Bulletin of Chinese Linguistics, and/or to the various LFK Award Committees.

優秀審查人獎設立於 2019 年，以感謝對李方桂中國語言學學會的《中國語言學集刊》及各種獎項 委員會提供優秀評審意見的貢獻。

Awards are given to reviewers who consistently supply reviews that are sound, instructive, knowledgeable, and fair, and provide constructive criticism and advice so that authors can strengthen their papers or proposals.

本獎頒予其意見一向直、諒、多聞而又公正的審查人, 其所提供的建設性的批評與建議, 能使作 者的文稿或計畫因之獲益。

These excellent reviewers help to maintain the high academic standards of BCL and the LFK Society.

《中國語言學集刊》及李方桂中國語言學學會之能保持高標的學術水準, 正是得力於這些優秀的 審查人。

(C) KONINKLIJKE BRILL NV, LEIDEN, 2020 | DOI:10.1163/2405478X-01302003

This is an open access article distributed under the terms of the CC BY-NC 4.o license. 